\title{
Mitteilungen
}

\author{
Facharztprüfung
}

\section{Facharztprüfung zur Erlangung des Facharzttitels für Physikalische Medizin und Rehabilitation}

Schriftlicher Teil der Facharztprüfung

Ort: Inselspital Bern

Datum: Samstag, 24. November 2018

Besammlung: $9.00 \mathrm{Uhr}$

Beginn der Prüfung: 9.30 Uhr

Dauer der Prüfung: 3 Stunden

\section{Anmeldefrist: 31. August 2018}

Weitere Informationen finden Sie auf der Website des SIWF unter www.siwf.ch $\rightarrow$ Fachgebiete $\rightarrow$ Facharzttitel und Schwerpunkte (Weiterbildung) $\rightarrow$ Physikalische Medizin und Rehabilitation

\section{Schweizerische Gesellschaft} für Handchirurgie

\section{Pressemitteilung zum Genfer Moratorium}

Am 1.1.2018 trat der neue TARMED-Tarif, der durch Bundesrat Berset festgesetzt wurde, in Kraft. Für die ambulant erbrachten operativen Leistungen der Handchirurgie wie auch anderer Disziplinen bedeutet das eine Kürzung der Abgeltung der ärztlichen Leistung von knapp 40\%. Da in der Handchirurgie die meisten Leistungen ambulant erbracht werden, ist nun eine Grenze überschritten, bei der diese Leistungen noch kostendeckend durchgeführt werden können. Die Genfer Handchirurgen führen aus diesem Grund seit dem 1.1.2018 keine ambulanten Wahleingriffe mehr durch. Mittlerweile haben sich auch die Genfer Gynäkologen, Orthopäden und Urologen diesem Moratorium angeschlossen.

Dieses Alarmsignal aus Genf zeigt, dass der bundesrätliche Tarifeingriff nicht der richtige Weg ist, die steigenden Kosten des Gesundheitswesens in den Griff zu bekommen. Vielmehr werden mit dieser Massnahme die Qualität der ärztlichen Versorgung und damit die Sicherheit der Patienten gefährdet.

Das aktuell gültige Referenzeinkommen, das aus der Grundversicherung generiert werden kann und auf dem der TARMED aufbaut, beträgt 207000 CHF. Einkommen von $>1000000$ CHF zu Lasten der Prämienzahler, wie von BR Berset moniert, sind aus tariftech- nischen Gründen überhaupt nicht möglich.

Die von der Politik gewünschte Verschiebung von der stationären hin zur ambulanten Behandlung wird durch nicht mehr kostendeckende Tarife von derselben Politik torpediert. Die Handchirurgen haben aus eigenem Antrieb ihren Beitrag zur Dämpfung der Kosten schon vor Jahren geleistet und 2012 eine Liste der ambulant durchzuführenden Operationen publiziert und umgesetzt schon lange bevor die Politik diese Listen erfunden hat.

Die Schweizerische Gesellschaft für Handchirurgie (SGH) hat vollstes Verständnis für die Aktion der Genfer Kollegen und begrüsst die damit angestossene Diskussion. Es gilt eine Finanzierungsform der ambulanten Leistungen zu finden, die den wirtschaftlichen Gegebenheiten gerecht wird und nicht ganze Berufsgruppen in dem Masse benachteiligt, dass deren wirtschaftliche Existenz in Frage gestellt wird. Durch ihr konstruktives Engagement in den Tarifkommissionen zeigen die Handchirurgen ihren Willen, ihren Teil zu einem gerechten, aber auch wirtschaftlichen Tarif beizutragen.

Die SGH setzt sich ein für die Sicherheit der Patienten und eine hohe Versorgungsqualität. Sie strebt an, dass der Zugang zu diesen Leistungen allen Patienten in gleichem Masse möglich bleibt, damit keine Zweiklassenmedizin entsteht, und verteidigt die effiziente, kostengünstigere ambulante Chirurgie. Nicht zuletzt ist es ihr ein Anliegen, die Attraktivität des Arztberufes und die des Handchirurgen zu sichern, damit diese hochstehenden Leistungen auch in Zukunft noch erbracht werden können.

Kontakt: Dr. med. Mario Bonaccio, Präsident SGH, mario.bonaccio[at]stgag.ch

Swiss Society of Cardiology

Swiss Amgen Cardiology Research Award 2018

\section{Rules of Entry}

1 The Swiss Amgen Cardiology Research Award is awarded for original research work in cardiovascular disease.

2 Prizes may be awarded for one or more research projects (to a maximum of three) provided that they are connected.

3 The manuscripts should be published or accepted for publication in a recognised peer-reviewed journal. Consideration can be given only to work published in the year in which the prize is awarded or in the year immediately preceding or following it.

4 Applicants should be the principal author of the work being submitted. Should several works be submitted, the applicant should be the principal author of at least one of them.

5 Applicants must be under 40 years of age on the deadline for submission. They must be Swiss citizens or working in Switzerland. Swiss citizens may also submit work carried out abroad provided that they are working in Switzerland at the time of the award.

6 The prize will be awarded annually by the Swiss Society of Cardiology together with Amgen Switzerland AG, normally on the occasion of the Annual Conference, but exceptionally at another event sponsored by the Society.

$7 \quad$ The prize winners will be selected by a prize jury whose members will be nominated by the Swiss Society of Cardiology, by agreement with the sponsor Amgen. The jury will consist of a chairman, representatives of all Swiss universities, some members of the board of Swiss Society of Cardiology as well as international experts. Members of the jury will be elected for four years and may be re-elected. A representative of Amgen Switzerland AG will be included as an observer.

8 The prize will be $30000 \mathrm{CHF}$, donated by Amgen Switzerland AG.

9 The prize winner undertakes to use the prize money of $30000 \mathrm{CHF}$ exclusively to continue his or her research. The money may be used for salaries, equipment or disposable materials.

Applications should be submitted by March 30, 2018, by e-mail to: info[at]swiss cardio.ch

Further information: Swiss Society of Cardiology, Karin Guldenfels, Dufourstrasse 30, 3005 Bern

More information: www.swisscardio.ch/ public/preise/preis_research.asp?l=de 


\section{Swiss Society of Cardiology}

\section{Otto Hess Trainee Award 2018}

The Swiss Society of Cardiology (SSC) has created the Otto Hess Trainee Award to recognize and support trainees in cardiology, who have made a significant contribution to research in the field of cardiology at an early stage of their career. The Award is named in memory of late Otto Martin Hess (1946-2011), a cardiologist, teacher and scientist with particular commitment to promotion of young researchers [1]. Trainees in cardiology who have accomplished at least two years of specialty training in cardiology or subspecialty training in pediatric cardiology, and who have been actively involved in cardiology research are invited to apply. The age limit is 32 years. Research activity must have resulted in either a doctoral thesis, a full-length publication as first author or a presentation at a major international cardiology congress (annual meeting of ESC, AHA, ACC or WCC) [2]. The work has to be accepted, published, or presented in the year before deadline of submission. Up to three awards of 5000 CHF each will be attributed each year (initially granted for a 4-year period).

Applications should be submitted by March 30, 2018 by e-mail (1 PDF file) with:

- application letter;

- curriculum vitae (1 page);

- list of publications and abstracts number of publications is not a major selection criterion);
- letter of support from the director of the institution (where the research has been conducted);

- thesis, publication, or abstract to be considered.

The signed application letter has to be sent also by post.

Address for submission:

Schweizerische Gesellschaft für Kardiologie Frau Karin Guldenfels

Dufourstrasse 30

3005 Bern

E-mail: info[at]swisscardio.ch

The rules of the Otto Hess Research Award providing more details on eligibility, the application procedure, and the award committee, can be downloaded from the website of the Swiss Society of Cardiology: www.swisscardio.ch/ public/preise/preis_ottohess.asp?l=de

Hans Rickli, President of the Otto Hess Trainee Award Committee Michael Zellweger, President of the Swiss Society of Cardiology

Cardiovascular Medicine. 2011;14(5):139-40

2 ESC, European Society of Cardiology; AHA, American Heart Association; ACC, American College of Cardiology; WCC, World Congress of Cardiology.

\section{Avenir Suisse}

Gesunde Spitalpolitik: Mehr Transparenz, mehr Patientensouveränität, weniger «Kantönligeist»

Das Schweizer Gesundheitssystem ist zwar sehr gut, seine Kosten relativ zum Bruttoinlandprodukt aber hoch; sie werden international nur noch durch die USA übertroffen. 2015 waren es 77,7 Mrd. Fr. bzw. 782 Fr. pro Kopf und pro Monat. 35\% der Gesundheitskosten fallen in den Schweizer Spitälern an. Es lohnt sich also, die bisherigen Reformanstrengungen in diesem Sektor unter die Lupe zu nehmen.

Mit der Einführung der Neuen Spitalfinanzierung im Jahr 2012 wurden wichtige Wettbewerbselemente in der Branche eingeführt: Seither können die Patienten das Spital in der ganzen Schweiz frei wählen, meistens auch zwischen öffentlichen und privaten Einrichtungen, und die Entschädigung der Spitäler erfolgt mit Fallpauschalen.

Erfreulicherweise blieb die hohe Qualität der Schweizer Spitäler in der Folge nicht nur erhalten, sondern erhöhte sich sogar leicht. Das Kostenwachstum ging zwar leicht zurück, konnte jedoch nicht, wie ursprünglich erwartet, gebremst werden. Auch die gewünschte Spezialisierung der Spitäler auf einzelne Leistungsgruppen ist ausgeblieben. Wenig Transparenz über die Qualität der

\title{
Aktuelles Thema auf unserer Website -
} www.saez.ch/de/tour-dhorizon

\section{\{FMH Die Ärzteschaft ist offen für neue Finanzierungsmodelle}

Repräsentative Studie im Auftrag der FMH.

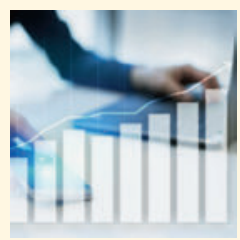

\section{Standortbestimmung und Ausblick}

\author{
Die Resultate der neuesten gfs-Umfrage zum Thema \\ «Medizinische Fachzeitschriften».
}


Leistungen, restriktive Aufnahmekriterien für die Spitallisten und intransparente Subventionen der Kantone zählen zu den Ursachen dieser Entwicklung.

Das neue Avenir-Suisse-Strategiepapier von Jérôme Cosandey, Noémie Roten und Samuel Rutz plädiert deshalb für eine dreiteilige Therapie im Spitalwesen:

1. Mehr Transparenz bei den Subventionen: Der Vergabeprozess der sogenannten gemeinwirtschaftlichen Leistungen (GWL) muss transparenter und fairer gestaltet werden, sei dies durch Ausschreibungen oder die explizite Zustimmung des jeweiligen kantonalen Parlaments. Allein 2015 wurden durch die Kantone 1,8 Mrd. Fr. Subventionen in der Form von GWL vergeben, bei teilweise sehr unterschiedlichen kantonalen Vorgehensweisen. Während der Kanton Zug 2015 nur 8 Fr. pro Einwohner ausgab, waren es 947 Fr. im Kanton Genf. 97\% der GWL kamen öffentlichen Spitälern zugute, was nicht zuletzt den Wettbewerb zwischen Privatspitälern und öffentlichen Spitälern verzerrt.

2. Aktiver Einbezug der Patienten: Patienten - also die Endkunden - sollen mitreden dürfen. Mit neuen Versicherungsmodellen, bei denen die Krankenkassen ihre Patienten vor Spitaleingriffen beraten, werden die Versicherten für Qualitäts- und Kostenunterschiede sensibilisiert. Wählen sie ein günstigeres, aber qualitativ gleichwertiges Angebot, werden sie für die resultierenden Kosteneinsparungen mit einer Gutschrift oder tieferen Prämien belohnt.

3. Abschaffung der kantonalen Spitallisten: Schweizweit gültige Qualitätsstandards sollen die kantonalen Spitallisten ersetzen. Sie werden auf wissenschaftlicher Basis durch eine finanziell und politisch unabhängige Organisation - eine Schweizer Agentur für Spitalqualität - ermittelt und kontrolliert. Alle Spitäler, die die Kriterien erfüllen, dürfen ihre Leistungen der Krankenkasse und dem Wohnkanton des Patienten verrechnen. Der Bund legt explizit nicht fest, wo welche Spitäler zu betreiben sind. Die Kantone bleiben aber für die Versorgung zuständig, wie es bereits in anderen Bereichen der Gesundheitspolitik erfolgreich praktiziert wird (Apotheken,
Arztpraxen, Spitex). Sofern der Markt die gewünschten Leistungen in ihrem Einzugsgebiet nicht hervorbringt, können die Kantone subsidiär auf regionale Bedürfnisse mit der Vergabe von gemeinwirtschaftlichen Leistungen eingehen.

\section{Beweglichkeit für öffentliche Spitäler}

Verlieren die Kantone die Möglichkeit, die eigenen Spitäler vor der Konkurrenz zu schützen und verschärft sich der Wettbewerb durch zunehmende Transparenz sowie ein höheres Kostenbewusstsein der Patienten, drängt sich eine Verselbständigung und letztlich eine Privatisierung der öffentlichen Spitäler auf. Diese brauchen mehr unternehmerische Flexibilität, um sich in einem zunehmend kompetitiven Umfeld behaupten zu können. Verselbständigung bedeutet dabei primär die Schaffung von klaren Corporate-Governance-Strukturen, in erster Linie eine Entpolitisierung der Aufsichtsgremien und Geschäftsleitungen. Auch die Wahl der Rechtsform kann einen Beitrag zur Verselbständigung leisten. Wichtig ist zuletzt, dass die Spitäler frei über ihre Immobilien verfügen und ihre Betriebsstandorte selber definieren können.

Publikation: «Gesunde Spitalpolitik - Mehr Transparenz, mehr Patientensouveränität, weniger «Kantönligeist» Jérôme Cosandey, Noémie Roten, Samuel Rutz, avenir debatte, 66 Seiten.

Kontakt: Jérôme Cosandey: +41 798282 787, jerome.cosandey[at]avenir-suisse.ch

\section{Interpharma}

\section{Steigende Gesundheitskosten - Anteil der Medikamente ist stabil}

Die Gesundheitskosten sind 2015 im Vergleich zum Vorjahr um 4,1\% gestiegen und betrugen insgesamt rund 77,8 Milliarden Franken. Stabil geblieben ist der Anteil der Medikamente, der 12,7\% der Gesundheitskosten ausmachte. Diese und weitere Informationen sind in der 37. Auflage des statistischen Standardwerks «Gesundheitswesen Schweiz 2018» zu finden.
Gesundheitskosten:

Anteil der Medikamente stabil

Die Kosten des Gesundheitswesens sind gegenüber 2014 um 4,1\% gestiegen und betrugen im Jahr 2015 insgesamt rund 77,8 Milliarden Franken. Das Bundesamt für Statistik hat die Methodik zur Erhebung der Daten an internationale Vorgaben angepasst. Dieser neuen Statistik zufolge machte die ambulante Behandlung im Jahr 2015 mit einem Anteil von $26,9 \%$ den grössten Kostenblock aus, gefolgt von der stationären Behandlung $(19,8 \%)$ und der Langzeitpflege (19,5\%). Bei den Medikamenten wurden erstmals auch im Spital stationär und ambulant abgegebene Arzneimittel in die Statistik einbezogen.

Insgesamt ist der Anteil der Medikamente an den Gesamtkosten mit 12,7\% stabil respektive leicht rückläufig. Insbesondere die regelmässigen Preisüberprüfungen der kassenpflichtigen Medikamente haben dazu geführt, dass der Index der Medikamentenpreise in den letzten Jahren gesunken ist.

Gesundheitswesen und Pharmaindustrie als wichtige Arbeitgeber

Neben dem Baugewerbe und dem Detailhandel ist der Gesundheitssektor einer der wichtigsten Arbeitgeber der Schweiz. Rund 435100 Personen arbeiteten im Jahr 2016 im Gesundheitswesen und in der Pharmaindustrie, womit jeder zwölfte Beschäftigte in diesen Branchen angestellt war. Die Pharmaindustrie hat die Zahl ihrer Arbeitsplätze seit 1995 mehr als verdoppelt. Mit über 40000 Beschäftigten stellte sie im Jahr 2016 rund $0,9 \%$ der Gesamtbeschäftigung in der Schweiz.

Weitere Informationen und die grafischen Darstellungen aus der Publikation «Gesundheitswesen Schweiz» sind auf der Interpharma-Website www.interpharma.ch unter «Fakten und Statistiken» zu finden. Die Broschüre kann als Publikation gratis bezogen werden.

Kontakt: Sara Käch, Leiterin Kommunikation, Tel. 06126434 14, Mobile 07920816 33, sara.kaech[at]interpharma.ch 